\title{
Effects of Employee Training on Organizational Effectiveness in NGOs Funded by UNHCR in Kenya: A Case of Care International in Kenya
}

\author{
Justa Njiru \\ St. Paul's University, Faculty of Social Sciences
}

\begin{abstract}
Community development is essential in any society. As actors of development, Non-Governmental Organisations (NGOs) need to have capable human resources to enable them achieve their mandate. The purpose of this study was to establish the effects of employee training on organisational effectiveness in NGOs funded by UNHCR in Kenya, with CARE International in Kenya (CIK) as the case study. This study adopted a descriptive research design. Primary data was collected through survey questionnaires containing open and closed ended questions. Data was analyzed using percentages and frequencies, descriptive statistics and regression analysis. The research findings established that employee training plays an essential role in promoting effectiveness and productivity of staff, which in turn contributes to overall organisational effectiveness. Concerning the purpose of employee training, the study revealed that it is important in enhancing staff development, implementation of CIK programmes and enhancement of interpersonal relations among others. The findings on the content of employee training revealed that it included a variety of content such as team working skills content, interpersonal relations content, communication relations content, leadership training content, time management and negotiation skills content as well technical and non-technical skills content. Results on the methods of staff training adopted indicated that the most popular training methods that were adopted by CIK included discussions which allowed people to offer varying views on a subject thus resulting to better understanding, E-learning where employees could $\log$ in at their convenience and access variety of resources, PowerPoint presentations which enabled visual illustrations and mentorship. The results on effect of staff training on organization effectiveness revealed that 68.4 percent of oragnisational effectiveness at $\mathrm{CIK}$ is attributed to staff training. Some of the key recommendations of the study include: CIK needs to find ways of ensuring all their staff are trained on both technical and soft skills as these not only affect the performance and productivity of staff, but also the overall effectiveness of the organisation, NGOs should train all their staff and not just management and office staff on basic skills/ areas to enhance their productivity at individual, team and organisational level among others.
\end{abstract}

Keywords: Employee Training, Organisational Effectiveness

DOI: $10.7176 /$ RHSS/11-20-05

Publication date:October $31^{\text {st }} 2021$

\section{Introduction}

The external environment of contemporary organisations, whether profit or not-for-profit is extremely dynamic and turbulent. Navigating this dynamism and turbulence requires that organisations put in place measures that can enable them to achieve their objectives. One of the measures that have turned out to be very important in achievement of organisational goals and objectives is employee training. Resilient and competitive organisations understand the essence of having in their payroll employees who are endowed with the right skills and knowledge. Adequately trained employees have the ability to perform their duties with a high degree of diligence and in addition gives the employee some feeling of satisfaction (Omosa \& Onditi, 2018).

Employee training has been embraced in many countries around the globe. For instance, in the United States of America, the concept seems to have gained roots as earlier as the 1980s when the Michigan school model also referred to as the "soft" Human Resource Management was proposed by Devanna, Formbrun and Tichy. The model which was developed in 1984 lays a lot of emphasis on training employees as a way of leveraging on human assets for the achievement of organisational strategic objectives (Enyioko \& Ikoro, 2018). A number of organisations in the United Kingdom and the European Union (EU) at large, especially the ones that appreciate the strategic significance of employee training have been promoting its adoption. These sentiments (that employee training plays a strategic role) are shared with the EU and several national institutions across Europe. However, the only difference lies in the level of investment organisations are willing to direct towards employee training (Shanahan, Garavan \& Carbery, 2015).

Enyioko and Ikoro (2018) define employee training as the effort and arrangements put in place by an organisation to enable their employees to acquire the necessary skills and knowledge in order to enhance the productivity of the organisation. Samwel (2018) also defines employee training as a process through which employees are brought to the awareness of the organisational objectives as well as imparting in them skills and information necessary for the achievement of the goals. It is therefore evident from the above definitions that 
employee training is all about imparting the right skills and knowledge that is aimed at enhancing the effectiveness of an organisation's performance over a period of time.

Employee training can be classified as either hard or soft skills, where hard skills refer to the more technical skills while soft skills are more about 'people' skills. Joshi (2017) defines soft skills as how a person relates with others i.e. their attitude, communication, emotional intelligence etc. He adds that these skills are as important as hard or technical skills as they complement each other. Some of the non-technical (soft) skills in employee training may include communication skills, emotional intelligence, leadership and management, problem solving just to mention but a few. A good number of organizations today recognize that soft skills development is imperative for maintaining relationships with co-workers and other stakeholders, which greatly impacts the effectiveness of an organization (Joshi, 2017).

Employee training has also been widely appreciated and practiced by many organisations in the African continent. Evidence from research reveals that a number of organisations both in the public and private sector consider employee training as an important tool in achieving effective performance. Samuel (2018) while conducting research on drilling firms in Geita Tanzania, asserted that the concept of employee training is one of great significance and avoiding it was detrimental to an organisation. Similarly, Enyioko and Ikoro (2018) while conducting a study on employee training in Nigeria admitted that it is a concept that is very critical in equipping staff with the required skills.

Equally in Kenya, employee training has been adopted by a number of organisations. Omosa and Onditi (2018) while studying the influence of employee training in Kisii County concurred with other researchers that employee training was very crucial in organizations since it enabled staff to acquire beneficial skills required for effective duty performance. Kariuki and Murimi (2015) also underscored the importance of employee training as a tool for empowerment of employees towards the achievement of organisational goals. This is an indication that employee training is a very important that organisations in Kenya have embraced.

Ehimuan (2020) defines organisational effectiveness as the capacity of an entity to deliver the expected outcome through the utilisation of minimal resources. Ehimuan further indicates that effectiveness of an organisation can be measured or evaluated through the level of growth achieved, the profitability of the entity as well as the level of stakeholder and customer satisfaction realised from the entity's activities. Nankervis, Rowley and Salleh (2016) also define organisational effectiveness as a concept that contains both quantitative and qualitative perspectives which affect internal and external stakeholders. They also seem to have held the same opinion with Ehimuan that effectiveness is larger than organisational performance.

Organizational effectiveness has been considered as an essential element in enhancing development processes. The contemporary business environment changes fast and rapidly than before and it is characterized by greater innovation and competition. The need for growth and not just survival is necessary in modern times than before. Organizations that can have an impact on development must endeavor to achieve effectiveness (Talbot, 2016). Talbot further argues that organizational effectiveness implies that an organization is able to better engage its employees, align its strategy and culture as well as develop better leadership for achievement of development objectives.

The significant question this research seeks to explore is whether there is any relationship between employee training and organisational effectiveness especially among the NGOs funded by UNHCR in Kenya. Evidence from research indicates that several studies have been conducted on employee training but most of them focus on its effect on organisational performance (Samuel, 2018; Enyioko and Ikoro, 2018). There seems to be greater inclination towards commercial organizations compared to NGOs. This study therefore focused on NGOs where more knowledge is required.

There are many agents in development, NGOs being one of them The United Nations in 1945 defined NonGovernmental Organization (NGO) as "any kind of organization provided that it is independent from government influence and is not for profit" (Czahajda, 2018). Non-Governmental Organizations (NGOs) have been in existence for ages but they grew rapidly in the latter part of the 20th century, as they increasingly played the role of community development assistance. There are millions of NGOs across the world today, playing different roles across the societies. NGOs across the world are increasingly being described as the third sector in development, owing to their involvement in different facets of development such as humanitarian assistance, environmental conservation, poverty eradication, advocacy, democracy building among many others (Lewis, 2010). NGOs are sometimes referred to as Non-Profits, Voluntary organizations or Civil Society Organizations, but this is largely dependent on different cultures.

In Africa and Kenya in particular, the NGO sector is considered a key development pillar in socio-economic development. NGOs in Kenya play a crucial role of complementing government efforts as the country strives to attain Sustainable Development Goals (SDGs) and Kenya's Vision 2030. In spite of the critical role NGOs play, they are faced with a myriad of problems ranging from poor accountability to poor governance. One of the main challenges cited by the 2018/2019 annual NGOs report is sustainability, since most of these organizations are in the evolving stage. Despite the high staff turnover resulting majorly from the short-term nature of projects is, 
$56 \%$ of NGOs trained their staff as a way of improving their effectiveness (NGOs Co-ordination Board, 2019).

CARE International in Kenya (CIK) is among the international NGOs operating in Nairobi, Kenya. It was among the very first NGOs to set up operations in Kenya in 1968 and for over 40 years, the organization has been a key player in socio-economic projects across the various counties in Kenya. CIK currently has 5 major programmatic areas including food and nutrition security, water, sanitation and hygiene, women and girls' economic empowerment, emergency and humanitarian assistance as well as health. Each of these programmes consists of several projects which are funded by different donors (among them UNHCR) and spread across various counties in Kenya.

CARE International Kenya has emerged as a strong development agent or actor based on the many development initiatives it has been implementing in many parts of the country. The NGO has transformed many lives through various ways. For instance, it has managed to provide opportunities to women and girls by enabling them gain access to productive assets and produce goods required at lower costs. CIK has also played a significant role in developing communities through provision of financial education through its group savings and loan approach. This has facilitated financial inclusion to the rural communities unable to afford conventional banking services. There are many more development projects the NGO has been engaged in and these have contributed significantly towards development of various communities in the country (CIK, 2020).

It is evident several studies have been conducted on employee training globally, regionally and locally in Kenya. However, a review of the literature from these studies reveals that most of these studies have mainly focused on exploring the relationship between employee training and the performance of organisations or performance of employees (Tambwe, 2015; Omosa and Onditi, 2018; Alshuwairekh, 2016). The studies therefore fall short of any significant knowledge on the effect of employee training on the effectiveness of an organisation. In addition, the studies have not investigated the effect of employee training on effectiveness of NGOs that are funded by a United Nations affiliated organisation such as the United Nations High Commissioner for Refugees (UNHCR). This leaves a research gap that requires to be bridged. This study therefore sought to bridge the research gap by investigating the effect of employee training on the effectiveness of NGOs funded by UNHCR.

\subsection{Literature Review}

\subsection{Purpose of Employee Training}

Employee training is one of the important practices adopted by most contemporary organizations NGOs included. Different authors have defined employee training in different ways. Waterhouse 2017 defined employee training the acquisition of knowledge, skills and attitudes to improve performance in one's current job. On the other hand, Walters and Rodriguez (2017) also consider education ad a process aimed at providing employees with the necessary instructions to enhance their performance. They further assert that training is a function that is usually part of the human resource section of the organisation and it is normally carried out due to different reasons or purposes.

According to Raheja et al., (2015), one of the purposes of conducting employee training in organizations is to address the weaknesses of employees that deter them from performing to their optimum in the workplace. Raheja further insinuates that worker may have several weaknesses and training them makes it possible to eliminate them in order to achieve the desired performance from them. Majid and Shakeel (2017) also indicate that organisations have tasks which they plan to achieve and therefore they need to train employees and impart in them the skills that are crucial for the achievement of the planned tasks. They further recommend that in the current competitive environment, effectiveness and efficiency in the workplace can only be achieved through appropriate employee training.

The other purpose of conducting employee training as asserted by Cacciattolo (2015) is because organisations consider workplace training as one form of workplace learning and can take many forms including in-house training which involves planned learning activities at work or outside of work. These could either be short training courses or sharing of information that comprises of a learning component to enable workers acquire technical and soft skills. According to Ibrahim et al, (2017), both technical and soft skills are crucial for every employee as they complement each other.

Barine \& Minja (2014) identify employee empowerment and team building as some of the human resource practices that catalyze organizational transformation. According to their book, training and development is one of the key employee empowerment aspects that can be embraced by the HR department to ensure organizational transformation takes place effectively (Barine \& Minja, 2014).

Vinesh (2014) also seems to agree with other researchers that employee training is the way through which organisations can overcome the weaknesses inherent in their employees. However, Vinesh further indicates that there are many more purposes of employee training which include enabling employees to be consistent in their duty performance, improvement in the satisfaction of the workers ain an organization, improvement in organisational productivity, enhancing service quality, cost reduction as well as minimizing supervision. This 
similar view is also shared by Raheja (2015) who agreed that employee training is important in reducing cost and improving the quality of services offered by an organisation.

Training content may differ from one organisation to another depending on the goals and objectives the organisation seeks to achieve. In most organisations, the content is normally tailored to assist employees achieve various skills which are critical for their duty performance. The following includes popular content captured in employee training programs as revealed by various researchers. There are many important soft skills that enable a person to maximize their potential in the workplace. Below is a highlight of a few of these:

Communication is one of the most important components in an organization since in whatever tasks people do, they cannot be successful if they fail to exchange not only general information, but also ideas. Lack of communication is identified by Minja and Barine (2014) as one of the most destructive things in achieving organizational transformation. They speak of poor communication as being a catalyst to lack of trust between employees and management (Barine \& Minja, 2014).

Employee training also includes leadership content that is aimed at improving the leadersip qualities of the workers. Leadership is increasingly considered an important component of organizational effectiveness (Barine \& Minja, 2014). Leaders and managers thus have great influence on organizational effectiveness. Barine \& Minja (2014) state that leadership is about influencing people towards achievement of a shared goal. They further argue that effective leaders understand the principles of leadership, which helps them to be more effective. This means that effective leaders have to learn as part of self-leadership.

According to Rush (2006), a leader's style of leadership greatly affects organizational productivity and that is why leaders need to understand the different styles of leadership and when to apply each of these. He adds that leaders also need to learn how to use the more participative team style, which is shown to highly influence productivity. Transformational style of leadership has been described by Barine and Minja (2014) as an attribute that can be learnt by managers. They define transformational leadership as leadership that brings about positive change in the followers. They describe individual coaching and workshops as the two main methods of transformational leadership training.

The other content included in training programs is that relating to teamwork and team building. For organisations to enable their workers to work in unity and as a team, there is need to include teamwork and team building content in training programs. Joshi (2017) argues that it may be easy to get the players but getting them to work together may not be that easy (Joshi, 2017). A team can be defined as a group of people working together to achieve a collective aim (Rush, 2006). Organizations create teams in order to achieve what could not be achieved by individuals. At the same time, teams in which people complement each other's strengths and weaknesses are much more productive as they are more motivated. Managers therefore have a role of building and maintaining teams that are productive as a way of improving organizational productivity (Rush, 2006).

Barine and Minja (2014) identify team building as one of the human resource practices that catalyze organization transformation. It is through training that building and maintaining teams that guide the transformation process to ensure that people in the organization are achieving the set vision can be achieved.

The other category of training content relates to interpersonal relationship skills. According to Joshi (2017), these are skills that help us relate positively with other people as individuals or in groups. These skills are important not only for staff, but also managers since they enable them to gain the support of employees without using an iron fist. Rush (2006) in his book mentions that many personnel managers concur that most employee turnover is directly attributable to relationship issues in an organization, especially between managers and employees.

Teams that do not have proper interpersonal skills find themselves having problems such as aggression, towards each other, poor attitudes, poor communication, mistrust, disrespect and interpersonal conflicts, all which affect their productivity as well as that of the organization (Rush, 2006). Organizations should thus make a deliberate effort to build the capacity of their teams to maintain healthy interpersonal relationships.

Subhashini and Vinesh (2014) assert that part of the important content of training programs adopted by organisations includes information concerning the goals and objectives of the organisation. They further argue that among the key areas that are usually covered include training concerning the vision and mission of the organisation, training on the strategic direction to be taken by the organisation, content relating to important policies in the organisation, information relating to organisational change and its implementation, key performance indicators as well as the core values that guide the activities of an organisation for a period of time into the future (Subhashini \& Vinesh, 2014).

Uzair, Majid and Shakeel (2017) also indicate that employee training may be tailored to equip the workers with knowledge concerning the short and the long term aims of an organisation. They further argue that organisations normally set both long and short term aims as they work towards implementing their corporate strategies. This makes it necessary for organisations to plan training programmes that can enlighten the employees on the aims of the organisation as well as the plans put in place for the achievement of these aims.

When new employees are hired into the organisation, they may require knowledge concerning the various 
operations in the organisation for them to perform their duties effectively. Most organisations may opt to train these employees on the various aspects of their operations and in this case the content includes the actual activities to be carried out by the employee on a day-to-day basis. This training may involve placing the new employee under the guidance of an existing employee who will take him/her through the required organisation operational procedures. It may therefore be done either on the job or off the job if there are many employees who require training on organisational operations (Milhem, Abushamsieh and Arostegui,2014).

\subsection{Employee Training Methods}

A number of authors have explored the various methods that are adopted by organisations in delivery of the training content. Milhem, Abushamsieh, and Aróstegui (2014) indicate that that there are several methods of employee training depending on what an organization seeks to achieve. They state that there can be on the job or off the job training, electronic learning method of training, conducting seminars for the employees, starting mentorship programmes for employees, taking employees to field trips or tours to learn or carrying out training through simulation in virtual workplace environments.

Raheja (2015) also cites a number of training methods that can be adopted by organisations. These methods include organizing lectures and conferences for the employees of an organisation. The lectures must be having enough content and must be motivating. The presenters must also have deep knowledge on the topic. Management games, case studies and role playing are also methods that can be used in delivering training content to the employees. The authors also mention transactional analysis where the employees are able to learn and understand the relationship with other employees.

\subsection{Organizational Effectiveness}

There have been numerous debates on the definition of OE, with some scholars even stating that OE is a concept that exists in people's minds. In simple terms, OE is defined as a measure of how well an organization is achieving its set objectives by aligning all the elements that are deemed important such as leadership, talent management, organizational structures, change management, capacity building etc (Dalvi \& Shelankar, 2018). Another definition is by Scott (2003) in Eng (2007) who defines OE as, “.... meeting organizational objectives and prevailing societal expectations in the near future, adapting and developing in the intermediate future, and surviving in the distant future"

Organizational effectiveness is quite a complex matter from its inception in the 50s. The complexity arises in that different organizations have different sets of goals and sometimes these goals are not easy to measure. Different schools of thought have tried to explore this concept and have concluded that unidimensional indicators of effectiveness are not valid. In the nonprofit sector, there is a great push by donors and other stakeholders to improve measures of performance within these organizations. A study by Lecy et al, (2012) on NGO and NPO effectiveness concluded that it would be very difficult to have standard measures of effectiveness across all organizations. They however suggested that variables such as managerial effectiveness, programme effectiveness, network effectiveness and legitimacy, all of which can be evaluated independently, can be considered to ease the burden of having to focus on organizational effectiveness as a whole (Lecy, Schmitz, \& Swedlund, 2012).

The concept of organizational effectiveness has evolved over a period of time to focus on business productivity. Many studies on Organizational Effectiveness have thus been business oriented (for-profit organizations). Few of these studies have covered non-profit organizations in developing countries. However, unlike in the commercial sector where parameters for organizational effectiveness such as profitability are standard, it is much more difficult to define and measure organizational effectiveness in NGOs as the objectives for each organization differ (Eng, 2007).

Dalvi \& Shelankar (2018) identify 3 levels of organizational effectiveness including employee performance, team performance and overall organizational performance. They argue that organizations are able to achieve high performance by maximizing the performance of individuals and groups within the organization. Accordingly, an organization is considered effective if all the components of the organization are satisfied. (Dalvi \& Shelankar, 2018)

In the NGO sector, Organizational Effectiveness not only concerns itself with how organizations are managed, but also other elements such as programme implementation, resource utilization, achievement of project objectives etc. (Balaraju, 2016). In fact, Faith-Based Nonprofit organizations consider organizational effectiveness as being able to meet the needs of their clients as well as being able to resolve the causes of these problems. This is in addition to other indicators including satisfaction of clients, stakeholder perceptions, financial reports and number of services offered (Jacobs \& Polito, 2012).

Many factors affect the effectiveness of an organization but of concern in this study is employee capacity building with reference to employee training. Indeed, Yang (2007) In (Dalvi \& Shelankar, 2018) states that "a significant relationship between organizational learning and organizational effectiveness exists." On the same 
trail, Kumar and Hsiao (2007) In (Dalvi \& Shelankar, 2018) argues that soft skills such as interpersonal skills, communication, and problem solving do contribute to the effectiveness of employees which leads to organizational effectiveness.

Measurement of effectiveness in any organization is paramount. However, unlike corporate entities, evaluating the performance of NGOs is not very easy. (Waal \& Olale, 2019) This is partly due to their focus on accountability to donors and not necessarily on other measures of effectiveness such as beneficiary satisfaction and overall organization effectiveness. This study narrows organizational effectiveness to three indicators, which will be considered throughout the study. These are; employee performance, programme implementation and organizational sustainability.

The quality of the human resources in any organization does affect, to a great extent, its ability to achieve the set goals (Cimatti, 2016). Employee performance is critical in any organization, no wonder performance assessment and evaluation is one of the most sought after tools by HR practitioners. According to Barine and Minja (2014), performance management is crucial in ensuring the employees and the organization in general are meeting the set goals. A study by Pradhan and Jena (2016) indicates that there are three dimensions of employee performance including task performance (high standard of work), adaptive performance (ability to adapt to change) and contextual performance (going the extra mile at work). (Pradhan \& Jena, 2016)

To ensure high performance of teams, managers have a key role to play. Many researchers, such as Armstrong agree that it is important for managers to effectively support their employees as this has a direct impact on their performance. Armstrong (2016) states that helping people develop their skills is one of the critical roles of a manager and this also serves the interest of the organization. By doing so, staff are more fulfilled in their work and they are able to perform better and further their careers. Providing learning and development opportunities to staff can also serve as a motivator. (Armstrong M. , 2016)

A programmatic way of working could either be a group of projects in one geographic area or a group of projects focused on one type of activity such as health, advocacy etc. Donors are continually preferring to fund this approach of working as they deem it more strategic and cheaper. Accordingly, OECD/DAC donors signed the Paris Declaration to using more Programme Based Approaches (PBAs) to bring better coordination between donors, and thus many INGO's have had to adapt this approach, though for some it has not been easy. (Giffen, 2009)

In spite of the adoption of the programme approach by some NGOs, projects still remain an important component of the NGO operations since programmes operate on the backdrop of projects. Project success or failure directly affects any given programme and so proper implementation of projects is critical to achieving programme effectiveness in NGOs. For project implementation to be deemed effective, it has to satisfy some fundamental criteria including timeliness, budget, and client satisfaction. Many studies have been carried out with respect to the topic on project implementation and there has been a common conclusion that certain factors determine the success of projects among NGOs. Some of these have been identified as communication, financing, planning, monitoring and evaluation etc (Thairu, 2014).

The managerial skills as well as the leadership style of project managers have been identified by many studies as playing a critical role to the success of projects. Other factors of project success include understanding of goals and objectives, ongoing management or relationships, attention to people issues and working relations within teams (Njeri \& Were, 2017). In their study where they sought to establish the determinants of project performance, they found out that management support plays a crucial role in project performance. This is coupled with collaboration, coaching, communication, employee relations and commitment (Njeri, 2017).

The environment in which organizations operate is becoming more and more competitive. This is coupled with the ever-changing dynamics of components such as client needs, technology and even people. Development agents including non-profit organizations have not been spared as funding trends keep changing as well as donor and government regulations. Organizations are therefore having to come up with strategies that will help them survive these changes in the long run. NGOs on their part are being compelled to adopt business-like strategies such as strategic planning, strategic management and strategic implementation of programmes, if only to stay in operation (Mukanga, 2011). In order to become sustainable, NGOs must embrace good governance as well as accountability. They must also be able to measure their performance as a way of improving organizational effectiveness and ensuring that they are improving their ability to deliver on their mandate (Adera, 2014)

One of the main challenges for NGOs in Kenya is sustainability, since most of these organizations are in the evolving stage. The 2018/2019 annual NGO Sector Report places the overall sustainability index at $66 \%$ (NGOs Coordination Board, 2019). An NGO can measure its sustainability by not only its ability to adapt to the changing external environment, but also the competencies of its staff. Edwards (1999) in (Mukanga, 2011) argues that the ability and commitment of the leadership within an organization is a critical aspect of sustainability. Leaders who are able to seek resources from donors, are keen on employee empowerment and are able to effectively solve problems in the organization are considered great drivers of organizational sustainability.

Sustainability in organizations denotes the ability of an organization to survive by capitalizing on the 
environment, society and environment. It is related to effectiveness and the two concepts are crucial to the success of the organization (Iwu et al, 2015). Their study sought to establish how the aspects of sustainability are a criterion for Organizational Effectiveness. They found out that organizational effectiveness is based on the ability of an organization to achieve its goals as well as the ability to cover costs, and that the two elements should be carried out in a sustainable manner. The researchers concluded that goal achievement and the successful implementation of projects to raise funds for sustainability are crucial for effectiveness (Iwu et al, 2015).

\subsection{Employee Training and Organisational Effectiveness}

A number of researchers have attempted to study the relationship between employee training and organisational effectiveness. For instance, Majid and Shakeel (2017) conducted a study on the importance of training and development in the workplace. Their study took a quantitative approach where secondary data was collected. It involved a sample of 200 respondents who were selected from the banking sector in Pakistan. The study results established that training employees had a significant impact on the performance of the targeted workplace. It was further evident from the study that skills and knowledge gained from training assist in improving organizational performance.

A study was conducted by Daniel (2018) on the effect of training on organisational performance. The study was conducted in Nigeria and involved three intuitions from the micro banking sector in Nigeria. The sample size of the study involved 304 respondents who were selected from the three institutions. The sample size was determined using Yamane formula for sample calculation. Primary data was collected for this research through a structured questionnaire. Descriptive and inferential statistics were employed in data analysis. The study findings indicated that training of employees had a positive influence on the productivity of an organisation. This study seemed to focus largely on performance hence the aspect of organisational effectiveness was not adequately addressed.

Another study was also carried out by Shekher and Reddy (2017) on the effect of employee training on organisational performance in the banking sector. The study focused on the Indian banking sector. The study adopted stratified random sampling to select a sample of 97 respondents who participated in the research. A questionnaire was adopted as the data collection instrument from the respondents. Correlation analysis and one sample test were applied in data analysis. The results from the study revealed that there was a significant positive relationship between the way employees perceived training and the performance or productivity of the organisation. This study also focused on the relationship between employee training and performance hence did not address effectiveness.

In Kenya, several studies have been carried out to try and establish the link between workplace training and employee performance including; (Asava, 2014), (Mohamud, 2014), (Atola, 2013) and (Musembi, Guyo, Kyalo, \& Mbuthia, 2018). While these studies have focused on employee training, none of them has attempted to explore the NGO sector in Kenya, especially with regards to organizational effectiveness. On the other hand, the majority of studies carried out within the NGO sector have put more emphasis on either factors affecting performance of projects or sustainability. Such studies include: (Wanja, 2017), (Mukanga, 2011), (Nyanje \& Wanyoike, 2016) and (Adera, 2014). Some studies have however attempted to explore the effect of capacity building on project performance in NGOs such as (Ouma, 2016). Nonetheless, there seems to be a gap in literature in the Kenyan context regarding the effect of capacity building and especially employee training on overall organizational effectiveness among NGOs.

Most of the available studies on employee training are focused on the commercial sector and organisational performance. In Africa for example, one such study carried out in the Ugandan telecommunications sector established that training and development has an impact on employees' job performance (Nassazi, 2013). Another study carried out in the banking sector in Lesotho also concluded that training influences employee performance (Motlokoa \& Monyoloc, 2018).

\subsection{Methodology}

This research employed a descriptive design, as it was quite precise in reporting the characteristics of the variables under investigation. This design was selected because it assisted in seeking the facts as they exist without the researcher's manipulation. Considered also in selecting the design was the fact that descriptive design is used to describe behavior, attitude, characteristics and values (Kothari, 2004). This study also employed quantitative methods.

This study was confined to CARE International in Kenya (CIK) as the case study. The organization was selected as a representative of the 28 NGOs that are funded by UNHCR in Kenya. The organisation implements one of the largest humanitarian programmes for UNHCR and enjoys a strong presence in Kenya.

This study was designed as a case study targeting one of the implementing NGOs funded by UNHCR in Kenya i.e. CIK. The target population included all the employees in CIK. The target population was therefore 
all the 165 employees of CIK (CIK, 2020).

CIK comprises of 94 Programme staff and 71 support staff, with each category divided into senior and junior staff (CIK, 2020). According to Mugenda (2010) at least 10 percent of the population is adequate for a sample. This study took $30 \%$ of the target population as the sample for the study. This translated to a total of 54 respondents.

The study adopted stratified random sampling method to select the sample. According to Kothari (2004), stratified random sampling method is used when the study population is not homogenous in nature, in which case the population is split into sub-populations (strata) and then a sample randomly selected from each stratum.

Primary data, collected through survey questionnaires consisting of open-ended and closed questions was used in this study. The questionnaire was semi structured containing both open and closed ended questions.

Quantitative data from the questionnaires was analyzed using descriptive statistics like frequency counts. Qualitative data from the questionnaires was coded and organized into themes and concepts that addressed the research questions and then analysed accordingly. Validated data was analysed using Microsoft Excel and manual methods to obtain relevant information. Regression analysis was also conducted to determine the effect of employee training on organisational effectiveness. The following regression model was used:

$\mathrm{Y}=\alpha+\beta 1 \mathrm{X} 1+\beta 2 \mathrm{X} 2+\beta 3 \mathrm{X} 3+\mathrm{e}$

Where $Y=$ Organisational effectiveness, $\alpha=\mathrm{y}$ intercept, $\beta 1$ to $\beta 3$ are regression weights for each of the independent variables respectively, $\mathrm{X} 1$ was the purpose of training, $\mathrm{X} 2$ was the content, $\mathrm{X} 3$ were the training methods whereas e was the error term.

\subsection{Findings}

4.1 Purpose of Employee Training in NGOs

The study results revealed that employee training serves different purposes at CIK. The first purpose of employee training at CIK was found to promote the effectiveness of the individual employees in performance of their roles in the organization. It was also established that employee training was necessary in order to equip employees with both technical and non-technical skills required in the effective performance of their duties and responsibilities.

The other purpose of employee training was found to be closely associated with staff development. The study results confirmed that CIK offered employee training as one way of contributing towards staff development among its employees. It was also established that employee training was very essential in ensuring effective implementation CIK programmes. Trained employees were more likely to perform better in the implementation the organizations programmes.

Still on the purpose of employee training, the results revealed that it serves an important role in improving and enhancing interpersonal relations among the employees of the organization. Employees who are properly trained gain team working skills and this provides them with the ability to relate well with colleagues. The improved interpersonal relations benefit the organization in many aspects including making it more effective.

It was further established that training in CIK focuses on a number of areas. A total of 18 areas of focus were identified and top among them were training on safety and security awareness, leadership management training, employee training in specific program areas such as Gender mainstreaming, WASH, Nutrition etc. and Professional Career Development were among key areas of employee training at CIK. Others that were identified include program management and occupational safety. Overall, the findings show that there is a mix of technical and non-technical employee training areas at CIK.

\subsection{Employee Training Content}

The research established that employee training at CIK included a wide variety of content. It was evident that training programmes at CIK contained content on team working skills. This was meant to equip employees with skills on how to work as team in order to achieve organizational goals. The content also included content interpersonal and communication skills. This was meant to equip the employees with skills on how to relate with colleagues and how to engage in sound and effective communication in the workplace.

Employee training content was also found to include aspects of leadership or manager training. This was important in nurturing leaders and managers who could make sound decisions for the benefit of the organization. The leadership training content also included work effectiveness content that was aimed at making employees more effective in their roles. The other aspect of training content was found to relate to time management and negotiation skills. CIK was found to include time management and negotiation skills content in is training programmes to assist its employees learn how to manage time better.

It was further evident that training programmes at CIK also included content on technical and non-technical skills. This was due to the understanding that for employees to work better there was need for them to possess both technical and soft skills. Training programmes were therefore designed to capture both technical and nontechnical content. 


\subsection{Methods Adopted in Employee Training}

A number of methods were found to be adopted by CIK in delivering training content to the employees during training programmes. The most popular training methods that were adopted by CIK included discussions which allowed people to offer varying views on a subject thus resulting to better understanding, E-learning where employees could log in at their convenience and access variety of resources, PowerPoint presentations which enabled visual illustrations and mentorship which involves taking an employee through the actual or real process or procedure of an activity.

There were other methods that were identified though they seemed not to be popular such as lectures where knowledge was imparted to the employees through lectures offered by professionals, seminars conducted outside the normal work environments, as well as case studies. It was further established that the training methodology that was adopted in offering training to the employees had a significant influence on the level of understanding and knowledge acquisition.

\subsection{Effects of Employee Training on Organizational Effectiveness}

The results on effect of employee training on organizational effectiveness revealed that employee training has a statistically significant effect on the effectiveness of CIK. According to the regression analysis results, it was clear that employee training explained 68.4 percent of the variance on organizational effectiveness at CIK. It was also established that among the three independent variables of the study, the purpose of employee training and the content of training programmes had statistically significant effect on the effectiveness of CIK.

Overall, based on the analysis of variance output, it was evident that the relationship between employee training and organizational effectiveness was statistically significant one. It was thus possible to arrive at a conclusion that employee training at CIK had a statistically significant effect on organizational effectiveness.

\subsection{Conclusions}

Employee training, including soft skills training, plays an essential role in promoting effectiveness and productivity of staff, which in turn contributes to overall organisational effectiveness. Both technical and nontechnical skills training are important as part of equipping staff with the requisite skills that enable them effectively execute their duties and also grow personally and professionally in their careers.

Employee training in areas such as team working and interpersonal skills does affect programme implementation in as much as it improves relationships among employees and beneficiaries. Leadership skills training for leaders and managers improves their effectiveness at work. Training programmes at CIK contained content on team working skills. This was meant to equip employees with skills on how to work as team in order to achieve organizational goals. The content also included interpersonal and communication skills, aspects of leadership or manager training, leadership training content also included work effectiveness content. The other aspect of training content was found to relate to time management and negotiation skills.

Training methodology affects the development of skills in staff. A combination of different training methods is thus key to ensuring that learners understand the concept of training since different people learn differently. PowerPoint presentation and use of discussions were the most commonly used training methods in employee training. The use of discussions is however the most preferred training method as it gives room for interaction among learners while the lecture method is the least preferred method as it doesn't create much room for learner participation and engagement.

A trainer's style of delivery is one of the key attributes of a trainer that influences the ability of learners to understand the content of training. The trainer's communication skills as well as their passion and attitude are also key attributes of a good trainer. Staff who undergo training perform better in their duties than their counterparts thus employee training contributes to the effectiveness of individual staff. Employee training improves individual qualities such as interaction with others and communication skills. It also does contribute to individual development.

Employee training affects the way operations are executed in various departments since these departments are made of individuals and employee training does affect the way individuals execute their duties, this automatically reflects at departmental level. Employee training contributes to the ability of an organisation to achieve its goals such as successful programme implementation.

\section{References}

Adera, M. P. (2014). Factors Affecting the Performance of NGOs in Kenya: A Case of Action Aid International. Nairobi: United States International University.

AIDSTAR-Two. (2011, January 2). Organizational Capacity Building Framework: A Foundation For Stronger, More Sustainable Hiv/Aids Programs, Organizations And Networks. Retrieved from Management Sciences for Health: https://www.msh.org/resources/organizational-capacity-building-framework-a-foundation-forstronger-more-sustainable 
Alshuwairekh, K. N. (2016). The Impact of Strategic Human Resource Management on Organizational Performance A Case Study for Saudi Arabia Basic Industries Corporation (SABIC). European Journal of Business and Management, 8(14), 29-49.

Aluvisia, H. K. (2016). Employee Performance in the Kenyan Public Sector. Nairobi: University of Nairobi.

Armstrong, M. (2014). A Handbook of Human Resource Management Practice. London: Kogan Page.

Armstrong, M. (2016). How to Manage People (Vol. 3). London: Kogan Page Limited.

Asava, M. M. (2014). Influence of Training on Employee Productivity in the Processing Sector: A Acase of Unga Limited Eldoret, Kenya. Nairobi: University of Nairobi.

Atola, J. A. (2013). Examining the Effects of Job Training on Employee Performance in Mobile Telephone Industry; A Case of Telkom Orange Nakuru, Kenya. Nairobi: Kenyatta University.

Balaraju, D. (2016). Organisational Effectiveness of NGOs with Reference to Personal Characteristics of Staff. IRA-International Journal of Management \& Social Sciences, 339-357.

Balaraju, K. (2016). Organisational effectiveness of NGOs with reference to personal characteristics of staff. Social Sciences, 4(02), 2016.

Barine, K., \& Minja, D. (2014). Transformational Corporate Leadership. Raleigh, NC 27658 USA: Integrity Publishers Inc.

Bastable, S. B., \& Dart, M. (2008). Developmental stages of the learner. Nurse as educator, 147-198.

Belanger, P. (2011). Theories of Adult Learning and Education. Toronto, Canada: Barbara Budrich Publishers .

Bhal, R. S. (2015). Training in Soft Skills and its Importance. International Journal of Management and Social Sciences Research (IJMSSR), 76-81.

Bhanot, S. (2009). Importance of Soft Skills for an Employee and for the Organization. SIES Journal of Management, 18-22.

Binsaeed, R. H., Unnisa, S. T., \& Rizvi, L. J. (2017). The Big Impact of Soft Skills in Today's Workplace. International Journal of Economics, Commerce and Management, 456-463.

Blakstad, O. (2008, June 17). Research Designs. Retrieved from Explorable.com: https://explorable.com/research-designs

Bordens, K. S., \& Abbott, B. B. (2008). Research methods and design: A process approach.

Cacciattolo, K. (2015). Defining Workplace Learning. European Scientific Journal, 243-250.

Cimatti, B. (2016). Definition, Development, Assessment of Soft Skills and their Role for the Quality of Organizations and Enterprises. International Journal for Quality Research, 97-130.

Clifford J. Drew, M. L. (2008). Ethical Issues in Conducting Research. In M. L. Clifford J. Drew, Designing and Conducting Research in Education (pp. 74-77). Thousand Oaks, CA: Sage Publications Ltd.

Conger, J. A., \& Benjamin, B. (1999). Building Leaders: How Successful Companies Develop the Next Generartion. San Francisco: Jossey-Bass Publishers.

Czahajda, R. (2016). Defining Factors Affecting Low NGO Performance. 14th Student's Science Conference (pp. 50-370). Wroclaw, Poland: Wroclaw University of Science and Technology.

Dalvi, D., \& Shelankar, M. (2018). Determinants of Organizational Effectiveness: An Empirical Study of Selected Public and Private Sector Bank in India. International Journal for Research in Engineering Application \& Management (IJREAM), 212-219.

Daniel, C.O. (2018) Effects of Training on Organizational Performance. Asian Journal of Business and Management, 6(5) 48-57

Deshpande, S. K., \& MM, M. (2017). A Study of Comparative Analysis of Impact of Employee training on the Em[ployees of Private and Public Sector Banks in teh City of Belgaum, Karnataka. International Journal of Economics \& Management Sciences.

Diamantidis, A. D., \& Chatzoglou, P. (2018). Factors affecting employee performance: an empirical approach. International Journal of Productivity and Performance Management, Vol. 68, 171-193.

Eng, S. G. (2007). Defining NGO Organisational Effectiveness in Indonesia: an Unfolding Journey. 5th ISTR Asia and PAcific Regional Conference. Manila: Academia.

Gahuri, P., Grounhaug, K., \& Strange, R. (2020). Research Methods in Business Studies- 5th Edition. London: Cambridge University Press.

Garavan, T., Shanahan, V., Carbery, R., \& Watson, S. (2016). Strategic human resource development: Towards a conceptual framework to understand its contribution to dynamic capabilities. Human Resource Development International, 19(4), 289-306.

Giffen, J. (2009, December). The Challenges of Monitoring and Evaluating Programmes. Retrieved from International NGO Training and Research Centre Web SIte: https://www.intrac.org/wpcms/wpcontent/uploads/2016/09/The-Challenges-of-Monitoring-and-Evaluating-Programmes.pdf

Goldstein, I. L., \& Ford, J. K. (2001). Training in Organizations. Belmont, CA: Wadsworth Group.

Heale, R., \& Twycross, A. (2015, August 10). Validity and Reliability in Quantitaive Studies. Retrieved from Research Gate: http://ebn.bmj.com/ 
Ibrahim, R., Boerhannoeddin, A., \& Bakare, K. K. (2017). The Effect of Soft Skills and Training Methodology on Employee Performance. European Journal of Training and Development, 1-19.

Iwu, C. G., Kapondoro, L., Twum-Darko, M., \& Tengeh, R. (2015). Determinants of Sustainability and Organisational Effectiveness in Non-Profit Organisations. Sustainability, 9560-9573.

Jacobs, G. A., \& Polito, J. A. (2012). How faith-based nonprofit organizations define and measure organizational effectiveness. International Journal of Organization Theory and Behavior, 29-56.

Jena, D. A. (2017). Importance of Soft Skills in Project Management. International Journal of Scientific Research and Management (IJSRM), 6173-6180.

Joshi, M. (2017). Soft Skills. Bookboon.com.

Kapur, S. (2015). Andragogy: The Adult Learning Theory. Indian Journal of Adult Education, 50 - 60.

Kariuki, A., \& Murimi, C. (2015). Employee empowerment and organization performance of Tata chemicals Magadi Ltd, Kenya.

Kaur, D., \& Batra, R. (2018, September). Effectiveness of Training and Soft Skills for Enhancing the Performance of Banking Employees. Indian Journal of Management, 11, 38-49. doi:10.17010/pijom/2018/v11i9/131614

Kiiru, M. (2004). How to Develop Resources for Christian Ministries. Nairobi: Uzima Press.

Kothari, C. R. (2004). Research Methodology. New Delhi: New Age International Publishers.

Kothari, C. R. (2004). Research methodology: Methods and techniques. New Age International.

Kumar, S., \& Hsiao, J. K. (2007). Engineers learn "soft skills the hard way": Planting a seed of leadership in engineering classes. Leadership and management in engineering, 7(1), 18-23.

Lecy, J. D., Schmitz, H. P., \& Swedlund, H. (2012). Non-Governmental and Not-for-Profit Organizational Effectiveness: A Modern Synthesis. International Journal of Voluntary and Nonprofit Organizations, Vol. $23,434-457$.

Leonard, K. (2019) Five Functions of Management \& Leading. Accessed Online 2/8/2020 from ttps://smallbusiness.chron.com/five-functions-management-leading-56418.html

Leonard-Barton, D. (1990). A dual methodology for case studies: Synergistic use of a

Lewis, D. (2010). Non Governmentl Organizations, Definition and History. In T. L. Science, International Encyclopedia of Civil Society (pp. 1056-1062). London: ResearchGate.

Majid, A.and Shakeel, S. (2017) Importance of Training and Development in the Workplace. International Journal of Scientific \& Engineering Research, 8(4) 498-504

Milhem, W., Abushamsieh, K., \& Pérez Aróstegui, M. N. (2014). Training Strategies, Theories and Types. Journal of Accounting, Business \& Management, 21(1).

Mohamud, A. M. (2014). The Effect of Training on Employee Performance in Public Sector Organizations in Kenya, the Case of NHIF Machakos County. Nairobi: University of Nairobi.

Motlokoa, M. E., \& Monyoloc, R. P. (2018). The Impact of Training on Employees' Performance: The CAse of BAnking Sector in Lesotho. International Journal of Human Resource Studies, 16 - 46.

Mthokozisi M., and Clifford, K., (2015). Training and development as a tool for improving basic service delivery; the case of a selected municipality, Journal of Economics, Finance and Administrative Science, $133-136$

Muda, I. (2014). Factors Influencing Employees' Performance: A Study on the Islamic Banks in. International Journal of Business and Social Science, 73-80.

Mugenda, O. M. \& Mugenda, AG (2010). Research methods: quantitative and qualitative approaches.

Mukanga, D. (2011). Sustainability strategies adopted by International NGOS in Nairobi, Kenya (Doctoral dissertation).

Musembi, A. K., Guyo, D. W., Kyalo, D. N., \& Mbuthia, D. (2018). Effect Of Employees' Soft Skills On Performance Of Public Energy Sector Projects In Kenya. International Academic Journal of Human Resource and Business Administration, 1-13.

Nankervis, A., Rowley, C., \& Salleh, N. M. (2016). Introduction: Human resource management and organisational effectiveness-an overview and synthesis. Asia Pacific Human Resource Management and Organisational Effectiveness, 1-13.

Nassazi, A. (2013). Effects of Training on Employee Performance: Evidence from Uganda. University of Applied Sciences.

NGOs Coordination Board. (2019). Annual NGO Sector Report 2018/2019. Nairobi: NGOs Co-Ordination Board.

Njeri, D. N., \& Were, D. (2017). Determinants of Project Performance in Non-governemntal Organizations in Kenya, A Case Study of Hand in Hand Eastern Africa. International Journal of Project Management, 61-79.

Nyanje, S. O., \& Wanyoike, D. M. (2016). Analysis of Factors Affecting the Implementation of NGO Projects in Nakuru County, Kenya. International Journal of Economics, Commerce and Management, 851-870.

Nzuve, S. N. (1999). Elements of Organizational Behavior. Nairobi: Nairobi University Press. 
Ohanyere, C. P., Ngige, C. D., \& Jacobs, C. J. (2021). Effect Of Training on Organizational Performance of Small and Medium Scale Enterprises in Anambra State, Nigeria. International Journal of Management and Entrepreneurship, 3(1), 67-75.

Omosa, J., onyango, M., and Onditi. A., (2018). Influence of employee training on organizational performance: a case of Kisii county government, Kenya. Int. J. Adv. Res. 6(10), 35-40.

Ouma, S. O. (2016). Influence of Capacity Buildig Programs on Project Performance in NGOs in Kenya: A Case of the Danish Refugee Council. Nairobi: University of Nairobi.

Pradhan, R., \& Jena, L. (2016). Employee Performance at Workplace: Conceptual Model and Empirical Validation. Business Perspectives and Research, 1-17.

Raheja, K. (2015). Methods of training and development. Innovative Journal of Business and Management, 4(02), 35-41.

Rodriguez, J., \& Walters, K. (2017). The importance of training and development in employee performance and evaluation. World Wide Journal of Multidisciplinary Research and Development, 3(10), 206-212.

Rush, M. (2006). Management: A Biblical Approach. Nairobi, Kenya: WordAlive Publishers.

Samwel, J. O. (2018). Impact of employee training on organizational performance-case study of drilling companies in geita, shinyanga and mara regions in tanzania. International Journal of Managerial Studies and Research, 6(1), 36-41.

Saunders, M., Lewis, P. H. I. L. I. P., \& Thornhill, A. D. R. I. A. N. (2007). Research methods. Business Students 4th edition Pearson Education Limited, England.

Scott, C. (2003). Organizational effectiveness: Its relationship to teacher efficacy and school climate. St. John's University (New York), School of Education and Human Services.

Serkan, B., \& Emir, C. (2014). Impact of Training and Development on Employees Performance in Bosnia And Herzegovina. European Researcher, 89(12) 2125-2132

Shekher, S., \& Reddy, P. R. (2018). Employee Training in Engineering Industries; A Cross-Case Approach. Asian Journal of Research in Business Economics and Management, 8(3), 31-44.

Subhashini, G. K., \& Vinesh, T. (2014, December). Educational leadership: The effects of leadership in students educational performance in engineering institutes. In 2014 IEEE International Conference on Industrial Engineering and Engineering Management (pp. 1051-1055). IEEE.

Talbot, L. (2016). Importance of Organizational Effectiveness to Success in Fast Changing Markets. Retrieved from website: https://www. questback. com/blog/the-importance-oforganizational-effectiveness-to-successin-fast-changing-markets.

Thairu, R. W. (2014). An analysis of implementation of NGO projects in Nairobi County. MBA thesis. Kenyatta University, Kenya.

The Adecco Group. (2017, January 24). The Soft Skills Imperative . Retrieved from The Adecco Group Website: https://www.adeccogroup.com/futuhreinsight/soft-skills-imperative/

Uzair, S., Majeed, A., \& Shakeel, S. (2017). Recruitment, Selection Policies and Procedure. Int. J. of Multidisciplinary and Current research, 5.

Vahedi, R. and Asadi A. (2013) Relationship between Management Styles and Performance of the Managers and Staff of Tax Administration Office of Tehran. European Online Journal of Natural and Social Sciences, 2(3) 2975-2983.

Vijayalakshmi, D. V. (2016). Soft Skills-The Need of the Hour for Professional Competence: A Review on Interpersonal Skills and Intrapersonal Skills Theories. International Journal of Applied Engineering Research , 2859-2864.

Vinesh, K. (2014). Role of training \& development in an organizational development. International Journal of Management and International Business Studies, 4(2), 213-220.

Waal, A. A., \& Olale, D. A. (2019). Analyzing the effectiveness of a Kenyan NGO with the HPO Framework. Global Business and Organizational Excellence, 38(2), 31-42.

Walters, K. and Rodriguez, J. (2017) The Importance of Training and Development in Employee Performance and Evaluation. WWJMRD2017; 3(10): 206-212

Wanja, P. (2017). Factors Influencing the Performance of Projects in NGOs Funded by WFP: A Case of Action Aginst Hunger. Nairobi: University of Nairobi.

Waterhouse, A. (2017, April). HR Insights, Careers. Retrieved from Frazer Jones: https://www.frazerjones.com blog

Yin, K. R. (2008). Case Study Research: Design and Methods, Fourth Edition, Applied Social Research Methods, Volume5,. Thousand Oaks, CA: Sage Publications. 